\title{
Genetics of resistance of spring barley to the agent Ustilago nuda
}

\author{
Bekhtold N.P.*, Orlova E.A. \\ Siberian Research Institute of Plant Production and Breeding - Branch of the Institute of Cytology and \\ Genetics, SB RAS, Novosibirsk, Russia \\ *email: Telichkinanina@mail.ru
}

The emergence and the reproduction of the new races is one of the main reasons for the loss of resistance to smut diseases by the varieties. The trait of the Ustilago nuda resistance is controlled by one, rarely two genes. The efficiency of genes changes over time and depends largely on the racial composition of the pathogen. Known about twenty Run genes, which to control resistance to pathogen. The genes Run 3, 6, 8, 15 are widely used in breeding practice all over the world. In most regions of the Russian Federation are effective highly against the pathogen the genes $R u n 3,6,8,12$. When determining the racial differentiation of the pathogen, the combined analysis system was used on an empirical set of barley and varieties with identified resistance genes. The inoculation of dust smut was used the vacuum method - V.I. Krivchenko. Infection of varieties with identified resistance genes made to identify the most effective resistance genes. Our data carried out about that Run 6 and Run 8 are the effective genes for Ustilago nuda resistance for the forest-steppe of the Ob region. The varieties containing the genes Run 3 + Run 6 (Bonanza, Jet. Morex), Run $3+$ Run 8 (Martoni) and Run $8+$ Run 15 (Suzdalets) are also resistant to the pathogen population. The high breeding value of the genes Run 3 and Run 12 for the conditions of the Novosibirsk region was not confirmed, because varieties Paragon and Galt carrying the Run 3 gene could not always provide protection against the pathogen $U$. nuda. Thus, the damage to the Paragon variety was from weak $(2,6 \%)$ to medium $(19,0 \%)$ annually. The maximum damage to the Galt cultivar over the years of research was $45,7 \%$. For further breeding work, it can be recommended to include in crosses varieties with effective genes for resistance to the local population of the pathogen $U$. nuda, such as Bonanza (Run 3, Run 6), CI 13664 (Run 8), Elf (Run 8), Suzdalets (Run 8, Run 15).

Acknowledgments: This work was supported by the Institute of Cytology and Genetics, SB RAS budget project No. 0259-2021-0018. 